\title{
Effects of income inequality on COVID-19 infections and deaths during the first wave of the pandemic: Evidence from European countries
}

\author{
David A. Sánchez-Páez ${ }^{1}$
}

\section{Abstract}

Evidence from research on infectious diseases suggests that income inequality is related to higher rates of infection and death in disadvantaged population groups. Our objective is to examine whether there was an association between income inequality and the numbers of cases and deaths during the first wave of the COVID19 pandemic in European countries. We determined the duration of the first wave by first smoothing the number of daily cases, and then using a LOESS regression to fit the smoothed trend. Next, we estimated quasi-Poisson regressions. Results from the bivariate models suggest there was a moderate positive association between the Gini index values and the cumulated number of infections and deaths during the first wave, although the statistical significance of this association disappeared when controls were included. Results from multivariate models suggest that higher numbers of infections and deaths from COVID-19 were associated with countries having more essential workers, larger elderly populations and lower health care capacities.

Keywords: COVID-19; income inequality; first wave; European countries

\section{Introduction}

In early 2020, a new coronavirus, SARS-CoV-2, also called COVID-19, arrived in Europe from China. Mass outbreaks were first recorded in Italy and Spain, and the virus then spread rapidly across the continent. Although European governments adopted emergency measures to contain the pandemic's advance, differences in the

\footnotetext{
${ }^{1}$ Centre for Demographic Research (DEMO), Université Catholique de Louvain. Louvain-la-Neuve, Belgium

${ }^{*}$ Correspondence to: David A. Sánchez-Páez, david.sanchezpaez@uclouvain.be
} 
numbers of infections and deaths have been observed between countries. While studies on the socioeconomic differences in the levels of COVID-19 infections and deaths have been conducted in several European countries, none of these studies compared these differences between countries.

The previous literature on this topic has pointed out that a disease can affect societies differently depending on the vulnerability of their populations due to conditions such as inequality or poverty. For instance, there is some evidence of a positive association between income or wealth and self-reported health status (Bor et al., 2017). Thus, health economists have argued that people with lower socioeconomic status face worse health outcomes than their counterparts with higher status, and that these differences can be explained in large part by two mechanisms: health behaviour and access to health care (Bor et al., 2017; Santerre and Neun, 2012). The first mechanism refers to the tendency of poorer and less educated people to be less well informed and less careful due to a lack of knowledge and awareness of their health. The second mechanism refers to evidence that poorer and less educated people tend to seek medical care less often, either because they cannot stop working, or because they are concerned about the costs associated with illness. Moreover, in the case of respiratory infectious diseases, social interaction is a crucial determinant of the likelihood of becoming ill. When infected people engage in economic or social activities, the risk of infection increases for healthy individuals (Jung et al., 2020). In the current pandemic, wealthier individuals have generally had more resources to self-isolate and telework, while people with lower incomes have often been performing essential or manual work that cannot be done remotely (Brown and Ravallion, 2020; Jung et al., 2020; Lekfuangfu et al., 2020; Papageorge, 2020; Takian et al., 2020). Thus, the transmission pathways and risk exposure levels have differed between socioeconomic groups. These societal inequities have highlighted the vulnerability of the least favoured groups.

Income inequality is one of the non-biological factors that has been used to explain adverse health outcomes, as it can affect the prevalence and consequences of poor health within societies. Compared to middle- and high-income households, low-income households tend to have lower life expectancy, higher mortality and worse health status, even in developed countries (Bor et al., 2017; Jijiie et al., 2019; Kawachi and Kennedy, 1999; Krisberg, 2016; Lynch et al., 1998, 2000; Meara et al., 2008; Neliss, 1999; Olshans et al., 2012; Pickett and Wilkinson, 2015; Rehnberg et al., 2019; Shkolnikov et al., 2007; Villegas and Haberman, 2014). Historically, life expectancy and mortality have been unequal between the richest and the poorest populations (Ahmed et al., 2020). In addition, more unequal societies tend to spend less on income redistribution policies, such as strengthening health care systems (Mello, 2006).

Disparities arising from income inequality have also been observed in analyses of the effects on populations of infectious respiratory diseases of viral origin. Studies on the impact of seasonal influenza have found associations between socioeconomic status and mortality, morbidity and symptom severity (Crighton et al., 2007; Tam et al., 2014). Evidence from research on the Spanish flu, a pandemic comparable to 
COVID-19 in terms of its global reach, indicates that mortality rates were higher among the poorest people (Bengtsson et al., 2018; Grantz et al., 2016; Mamelund, 2006; Murray et al., 2006; Sydenstricker, 1931). However, no such mortality differences by socioeconomic status were found in countries with low levels of economic and social inequality (Rice, 2005; Summers et al., 2014). The findings of research on the effects of a more recent pandemic, the $2009 \mathrm{H} 1 \mathrm{~N} 1$ influenza, were similar. For example, several studies have found that H1N1 influenza mortality was higher among the most deprived social groups in developed countries (Biggerstaff et al., 2014; Lowcock et al., 2012; Rutter et al., 2012), while a cross-country analysis showed that H1N1 influenza mortality was higher in low-income than in high-income countries (Charu et al., 2011). The socioeconomic disparities in H1N1 influenza mortality and morbidity have been attributed to differences in levels of exposure to the virus, susceptibility to the disease, and access to health care once the disease had developed (Rutter et al., 2012).

The evidence that large income differences have damaging health and social consequences is, therefore, strong. Moreover, it has been argued that the COVID-19 pandemic could exacerbate these differences, as inequality could increase the pace of the spread of the disease (Ahmed et al., 2020; Brown and Ravallion, 2020). For instance, it has been observed that people in countries with greater income inequality have been less likely to adopt preventive health measures, such as isolation, physical distancing, and the use of masks and hand disinfection (Elgar et al., 2020; Papageorge, 2020; Pirisi, 2000). In addition, initial findings on the effects of the pandemic suggest that people in the lower socioeconomic groups have been facing more severe consequences, and that income inequality might explain the differences in the numbers of cases and deaths within and across countries. Results from the United States show that infection and mortality rates from COVID-19 are higher in the states and counties where income inequality or poverty levels are higher (Brown and Ravallion, 2020; Chen and Krieger, 2020; Jung et al., 2020; Mollalo et al., 2020; Mukherji, 2020; Oronce et al., 2020). For Brazil, there is evidence of a positive and significant correlation between income inequality and COVID19 mortality (Demenech et al., 2020; Martines et al., 2021). Studies conducted in Germany, Israel and Spain have shown that infection rates in these countries have varied based on income inequality, with socioeconomically disadvantaged populations being more likely to be infected (AQuAS, 2020; Arbel et al., 2020; Wachtler et al., 2020). A comparative study of the 10 countries worldwide that have been the most affected by the pandemic used a multidimensional index, including income inequality, to show that the worse off a country is, the greater the impact of COVID-19 has been (Ruiz Estrada, 2020). A study comparing the number of deaths per day in 80 countries concluded that mortality tends to increase more rapidly in countries where inequality is greater (Elgar et al., 2020).

During the first pandemic wave, one of the measures governments used to deal with the threat was the imposition of severe restrictions on mobility, which in most cases meant that the population was ordered to stay home whenever possible. Teleworking became widespread for all non-essential workers. However, 
essential workers, mostly in manual or machine-based activities, had to continue working face-to-face and commuting to their workplaces, or risk losing their jobs (Adams et al., 2020; Ahmed et al., 2020; Lekfuangfu et al., 2020). Studies conducted in England and Wales and in Thailand found that the use of public transport to commute to work was associated with increased risk of COVID-19 infection (Lekfuangfu et al., 2020; Sá, 2020). Analyses of geolocation data from the United States showed that lower-income workers continued to move around during lockdowns, while higher-income workers tended to stay at home and limit their exposure (Buchanan et al., 2020). Another study concluded that the U.S. counties with the highest levels of income inequality had higher rates of infection, as the lower-income workers in these counties were less able to maintain social distancing because of their work activities (Brown and Ravallion, 2020).

The research to date has analysed the effects of income inequality on variations in COVID-19 infections within countries. However, only a few cross-country comparative studies have analysed how the COVID-19 pandemic has affected countries depending on their socioeconomic differences, and none of these studies has focused on Europe. Thus, our objective is to examine whether there was an association between income inequality and the numbers of cases and deaths during the first wave of COVID-19 in European countries. Although Europe is considered to have lower inequality than other regions, evidence from past pandemics has shown that even in European countries, there have been differences in health outcomes associated with income distribution. Due to the rapid spread of the virus, and to a lack of knowledge about how to combat it among both scientists and the general public, governments did not have a plan for protecting the most deprived social groups. Thus, analysing the effects of the first wave of the COVID19 pandemic on European countries can help us examine the differences in health outcomes associated with socioeconomic inequities. More unequal countries were already more likely to have adverse health outcomes and weaker health care systems. Therefore, income inequality may have played a significant role in exacerbating these existing vulnerabilities during the COVID-19 pandemic.

\section{Data and methods}

To conduct our analysis, we use as dependent variables the cumulated number of infections and deaths at the end of the first wave. We have collected the daily number of COVID-19 cases and deaths from Our World in Data (2020), one of the specialized data repositories that has compiled global information on the evolution of the pandemic.

It should be noted that although the virus spread rapidly through Europe, not all countries were affected at the same time, and the evolution of the disease differed from one country to another. Therefore, we have harmonized the analysis period by estimating the duration of the first wave for each country using the reported number of cases per day from January 2020 to January 2021. To do so, we first smoothed 
the daily number of infections using a seven-day moving average. Then, we used a local polynomial regression - i.e., locally estimated scatterplot smoothing (LOESS) - to fit the trend. As the result is a sinusoidal type pattern due to the multiple waves, we considered the first wave to be the first hump of the LOESS fit. We defined the onset as the day on which the 100th case was reported, and the end as the day on which the slope of the fitting curve did not show a statistically significant decrease after the number of cases per day was at least half that at the peak.

For illustrative purposes, Figure 1 shows the smoothed trends and fitting curves in several countries. For most European countries, the first wave lasted from midMarch to late June, and it did not go beyond August 2020 in any European country. Although the number of infections per day was already declining by the end of January 2021 in Moldova and Ukraine, these two countries were excluded as they showed no signs of having completed the first wave. Table 1 displays the details of the first wave.

Our variable of interest is income inequality. To measure income inequality, we use the Gini index, which is distributed from zero, indicating totally equal distribution, to 100 , indicating totally unequal distribution. We collected the latest reported Gini index results from the World Bank Open Data repository (World Bank, 2020). Figure 2 displays the Gini index values across the countries included in our sample. The Gini index values range from 24.2 to 40.4 , and the sample mean is 31.7 . Europe is considered the most egalitarian continent in the world. At the regional level, the Scandinavian and Eastern European countries generally have the most egalitarian income distributions, while income inequality tends to be highest in the Balkan countries.

Since recent studies have found that certain socioeconomic and demographic characteristics can help to explain how COVID-19 has affected a particular country, we include them in our analysis to control our estimates. Most of these studies agree that the relevant characteristics include age structure, as age might reflect the incidence of pre-existing health conditions (Brown and Ravallion, 2020; Esteve et al., 2020; Gardner et al., 2020; Kashnitsky and Aburto, 2020; Nepomuceno et al., 2020); poverty and education, as they are strong determinants of health outcomes (Bor et al., 2017; Brown and Ravallion, 2020; Santerre and Neun, 2012); numbers of essential workers, as these workers are more exposed to infection because they use public transport and have face-to-face contact (Adams et al., 2020; Ahmed et al., 2020; Lekfuangfu et al., 2020; Sá, 2020); population density, as infected and uninfected individuals are more likely to interact in denser settings (Brown and Ravallion, 2020); social contact, as the risk of infection increases at higher levels of social contact (Aparicio and Grossbard, 2020; Cristini and Trivin, 2020); and health care capacities, as the pandemic has exposed vulnerabilities in health care systems (Hopkins Tanne et al., 2020; Mollalo et al., 2020; Nepomuceno et al., 2020), and health care capacities have played a role in how hard each country has been hit by the disease. To include these controls in our analysis, we collected information from various sources, while always using the latest reported data for each variable. 
Figure 1:

Smoothing and fitting the number of infections per day in selected countries over a 180-day period
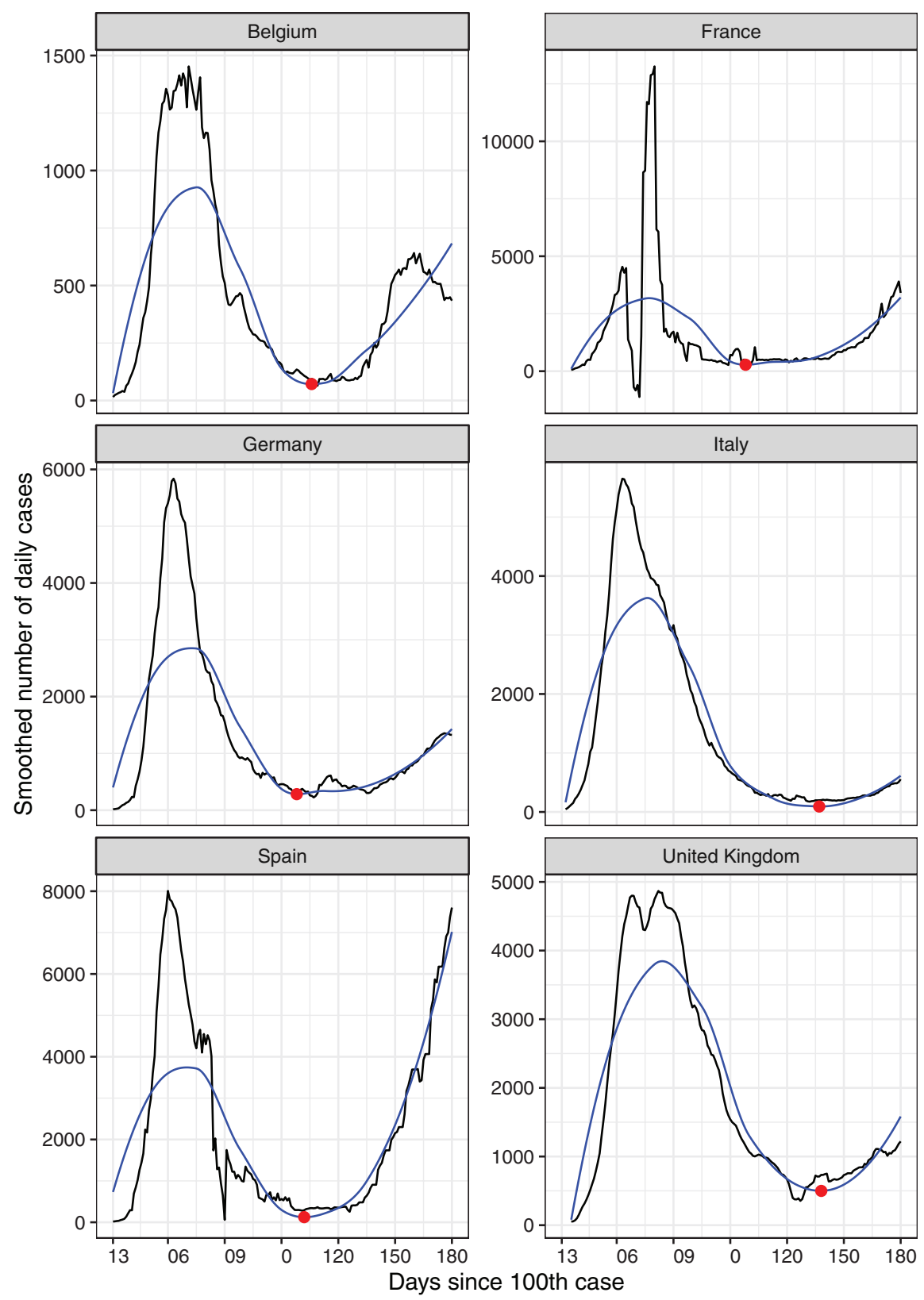

End of first wave $-\rightarrow$ LOESS fit 
Table 1:

Details of the first wave of COVID-19 in European countries

\begin{tabular}{|c|c|c|c|c|c|c|}
\hline \multirow[b]{2}{*}{ Country } & \multirow[b]{2}{*}{ 1st case } & \multicolumn{5}{|c|}{ First wave } \\
\hline & & Start & End & Days & $\begin{array}{l}\text { Total } \\
\text { cases }\end{array}$ & $\begin{array}{r}\text { Total } \\
\text { deaths }\end{array}$ \\
\hline Albania & March 09 & March 23 & May 14 & 53 & 898 & 31 \\
\hline Austria & February 25 & March 08 & May 22 & 76 & 16,436 & 635 \\
\hline Belarus & February 28 & March 30 & August 17 & 141 & 69,589 & 613 \\
\hline Belgium & February 04 & March 06 & June 19 & 106 & 60,476 & 9,695 \\
\hline $\begin{array}{l}\text { Bosnia and } \\
\text { Herzegovina }\end{array}$ & March 05 & March 22 & May 28 & 68 & 2,462 & 153 \\
\hline Bulgaria & March 08 & March 20 & May 25 & 67 & 2,433 & 130 \\
\hline Croatia & February 25 & March 19 & June 02 & 76 & 2,246 & 103 \\
\hline Cyprus & March 09 & March 23 & June 23 & 93 & 990 & 19 \\
\hline Czechia & March 01 & March 13 & May 20 & 69 & 8,721 & 304 \\
\hline Denmark & February 27 & March 10 & June 24 & 107 & 12,815 & 603 \\
\hline Estonia & February 27 & March 14 & July 04 & 113 & 1,993 & 69 \\
\hline Finland & January 29 & March 13 & July 09 & 119 & 7,273 & 329 \\
\hline France & January 24 & February 29 & June 05 & 98 & 192,450 & 29,114 \\
\hline Germany & January 27 & March 01 & June 06 & 98 & 185,450 & 8,673 \\
\hline Greece & February 26 & March 13 & May 28 & 77 & 2,906 & 175 \\
\hline Hungary & March 04 & March 21 & July 03 & 105 & 4,172 & 588 \\
\hline Iceland & February 28 & March 12 & May 23 & 73 & 1,804 & 10 \\
\hline Ireland & February 29 & March 14 & June 30 & 109 & 25,473 & 1,736 \\
\hline Italy & January 31 & February 23 & July 08 & 137 & 242,149 & 34,914 \\
\hline Latvia & March 02 & March 20 & June 23 & 96 & 1,111 & 30 \\
\hline Lithuania & February 28 & March 22 & June 09 & 80 & 1,727 & 72 \\
\hline Luxembourg & February 29 & March 17 & May 23 & 68 & 3,990 & 109 \\
\hline Malta & March 07 & March 23 & June 24 & 94 & 665 & 9 \\
\hline Montenegro & March 17 & March 31 & May 29 & 60 & 324 & 9 \\
\hline Netherlands & February 27 & March 06 & June 22 & 109 & 49,866 & 6,109 \\
\hline Norway & February 26 & March 06 & June 28 & 115 & 8,855 & 249 \\
\hline Poland & March 04 & March 14 & June 30 & 109 & 34,393 & 1,463 \\
\hline Portugal & March 02 & March 13 & August 02 & 143 & 51,463 & 1,738 \\
\hline Romania & February 26 & March 14 & June 07 & 86 & 20,479 & 1,333 \\
\hline Russia & January 31 & March 17 & August 12 & 149 & 900,745 & 15,231 \\
\hline Serbia & March 06 & March 19 & June 01 & 75 & 11,430 & 244 \\
\hline Slovakia & March 06 & March 18 & June 02 & 77 & 1,522 & 28 \\
\hline Slovenia & March 05 & March 13 & May 27 & 76 & 1,471 & 108 \\
\hline Spain & February 01 & March 02 & June 11 & 102 & 242,707 & 27,136 \\
\hline Sweden & February 01 & March 06 & August 29 & 177 & 83,958 & 5,821 \\
\hline Switzerland & February 25 & March 05 & June 05 & 93 & 30,936 & 1,921 \\
\hline United Kingdom & January 31 & March 02 & July 17 & 138 & 294,803 & 41,060 \\
\hline
\end{tabular}


Figure 2:

\section{Gini index in European countries}

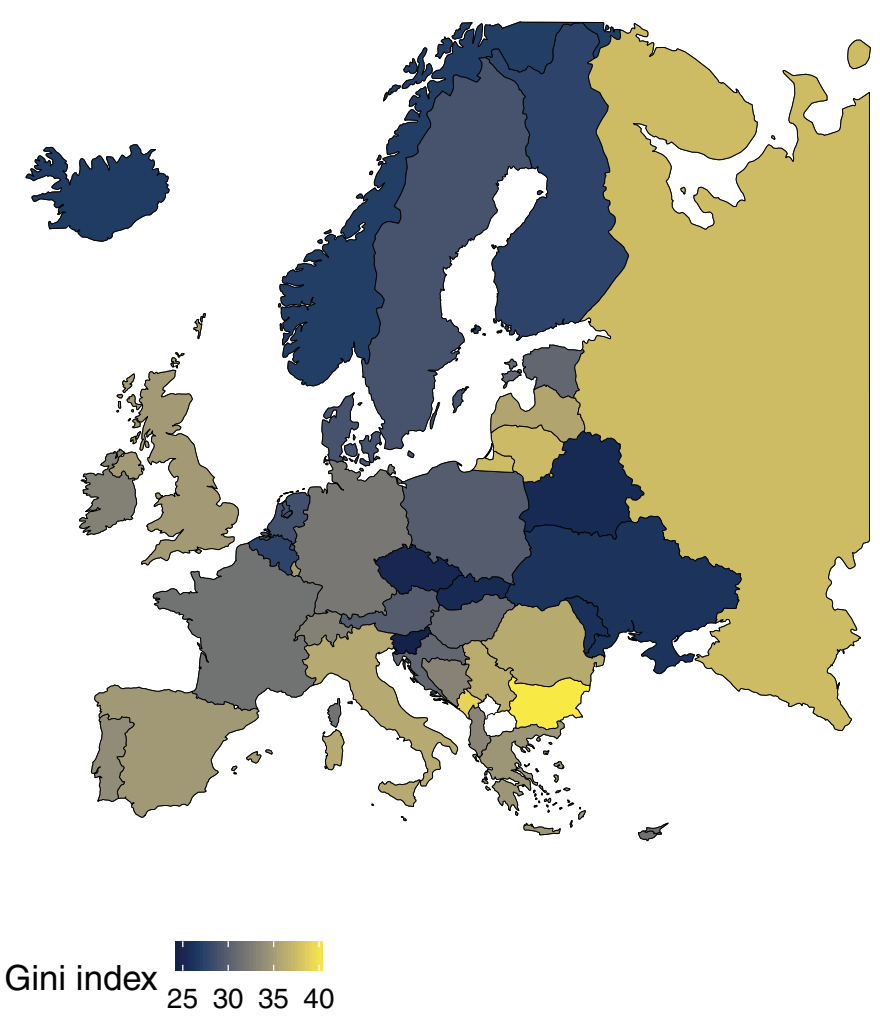

To account for (i) age structure, we use the latest projection of total population from the World Population Prospects (United Nations, 2020) to compute the share of people aged 65 and older. For (ii) education, we use the share of population with at least upper secondary school for the population aged 25 and older ${ }^{1}$ (UNESCO, 2020). For (iii) essential workers, we use the share of people working in industry ${ }^{2}$ (ILO, 2020). For (iv) population density, we use the share of the population living in urban areas (United Nations, 2018). For (v) social contact, we use the number of flight departures (domestic and international) (World Bank, 2020). For health capacities, (vi) we use the number of physicians - i.e., generalist and specialist medical practitioners - per thousand inhabitants (World Bank, 2020), and (vii)

\footnotetext{
Path to data is SDG/Sustainable Development Goals 1 and 4/Sustainable Development Goal 4/Target 4.4/Share of population by educational attainment.

2 This information can be found as part of the "Employment distribution by economic activity" indicator.
} 
the number of hospital beds per 10,000 inhabitants (WHO, 2020). In addition, to account for any possible effects of a government's response to the crisis, we include two controls: the number of days between the first case and the localized or national lockdown (Dunford et al., 2020), and the ideological orientation of the government (CIDOB, 2021). In the first case, we consider the possibility that a late response could have contributed to the pandemic hitting the country harder. It should be noted that only Belarus did not adopt a lockdown policy. Therefore, we use the duration of the first wave as the number of days. In the second case, we consider the possibility that the ideological orientation of the government may have had an effect on the dependent variables and the variable of interest through the unobserved preferences (of individuals or governing parties) regarding income redistribution, or through measures taken to control the pandemic. To account for this possibility, we include a dichotomous variable that takes the value of one when the ideology is right or centre-right, and a value of zero for other ideologies.

We use data from all European countries with complete information. Thus, we include 37 European countries in our study, and our sample covers $94 \%$ of Europe's population.

We first estimate a bivariate model for each dependent variable, including only the Gini index as an explanatory variable. Second, we estimate multivariate models that include the controls specified above. The reported numbers of cases and deaths are the count data. Poisson distribution is used for modelling the number of times an event occurs in an interval of time or space. Poisson regression assumes that the logarithm of its expected value can be modelled by a linear combination of its parameters:

$$
\begin{aligned}
\log (E(Y \mid X)) & =X \beta \\
E(Y \mid X) & =e^{X \beta}
\end{aligned}
$$

where $X$ is a vector of independent variables, and $\beta$ is the set of parameters. While a Poisson model assumes that the variance $(\operatorname{var}(Y))$ is equal to the mean $(E(Y \mid X)=$ $\mu$ ), this assumption does not always hold true. When the variance is greater than the mean - i.e., when there is overdispersion - either quasi-Poisson or negative binomial regression models are more appropriate (Ver Hoef and Boveng, 2007). Quasi-Poisson models assume that the variance is a linear function of the mean, $\operatorname{var}(Y)=\theta \mu$, where $\theta$ is an overdispersion parameter. Negative binomial models assume that the variance is a quadratic function of the mean, $\operatorname{var}(Y)=\mu+\alpha \mu^{2}$, where the overdispersion is the multiplicative factor $1+\alpha \mu$. Overdispersion tests on our sample showed that the null hypothesis $\operatorname{var}(Y)=\mu$ is rejected. Then, following Ver Hoef and Boveng (2007), we have performed a diagnostic analysis (not shown) plotting the fit of the variance, using averaged squared residuals, to the mean. The results suggest that the quasi-Poisson model fits the variance-mean relationship better.

Finally, it should be noted that the values of the number of infections and deaths vary widely across countries due to their different population sizes. Thus, we include 
in all regressions the log of total population as an offset,

$$
\log (E(Y \mid X))=\log (\text { pop })+X \beta
$$

then,

$$
\log (E(Y \mid X))-\log (\text { pop })=\log \left(\frac{E(Y \mid X)}{\text { pop }}\right)=X \beta
$$

\section{Results}

In Europe, the first wave lasted an average of 98 days (see Table 1). During this time period, there were 2,581,181 confirmed COVID-19 cases and 190,564 confirmed deaths from the disease in the 37 countries included in our study. The longest first waves were in Sweden (177 days), Russia (149 days) and Portugal (143 days); while the shortest first waves were in Albania (53 days), Montenegro (60 days) and Bulgaria (67 days).

The upper panel of Figure 3 shows the cumulated number of infections per million population (p.m.p.) during the first wave by country. The solid line represents the average of the sample, which was 3,707.5 infections p.m.p. It is not a coincidence that the countries with the highest numbers of infections were Sweden $(8,313.3$ infections p.m.p.) and Belarus (7,364.4 infections p.m.p.). In both countries, no measures were taken to restrict social contact, which also explains why Sweden had the longest first wave. The countries with the lowest numbers of infections, coinciding with the shortest first wave durations, were Slovakia and Greece (both with 279 infections p.m.p.), followed by Albania (312 p.m.p.) and Bulgaria (350.1 p.m.p.).

The lower panel of Figure 3 displays the cumulated number of deaths during the first wave of COVID-19. The solid line shows the average in our sample, at 273.7 deaths p.m.p. Belgium had the highest mortality rate by far, at 836.5 deaths p.m.p., followed by the United Kingdom (604.8 deaths p.m.p.), Spain (580.4 deaths p.m.p.), Italy (577.5 deaths p.m.p.), Sweden (576.4 deaths p.m.p.) and France (446 deaths p.m.p.). Except in Sweden, a higher infection rate in a country did not necessarily predict higher mortality. Among the possible explanations for this finding are that complications from infections might have been exacerbated by vulnerabilities at the individual level, and that the responsiveness of the countries' hospital systems could have varied.

The upper panel of Figure 4 plots the Gini index and the number of infections. Pearson's correlation estimation suggests that there was a moderate positive association of $0.287(95 \% \mathrm{CI}=0.076-0.474)$ between these two variables. The per capita risk of infection increased by $1.08(95 \% \mathrm{CI}=1.03-1.14$, se $=0.028)$ for every unit of increase in the Gini index (see column [1] of Table 2). After including controls (see column [2] of Table 2), the association became weaker (1.04), such that the confidence interval now included one $(95 \% \mathrm{CI}=0.98-1.09$, se $=0.027)$. 
Figure 3:

Cumulated number of infections and deaths per million population (p.m.p.) during the first wave of COVID-19
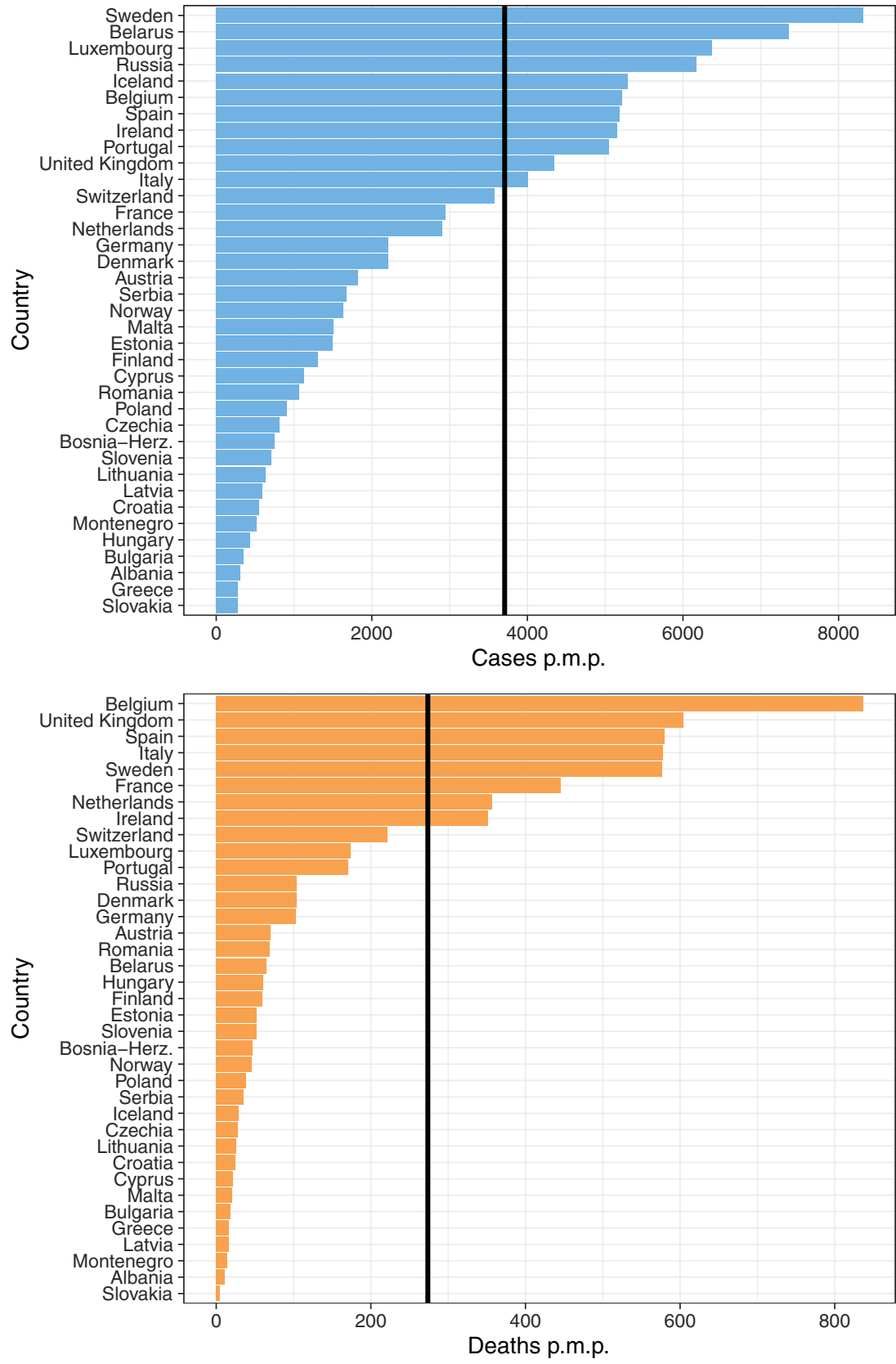

EU average - 
Figure 4:

Number of infections and deaths per million population (p.m.p.) during the first wave of COVID-19 and the Gini index
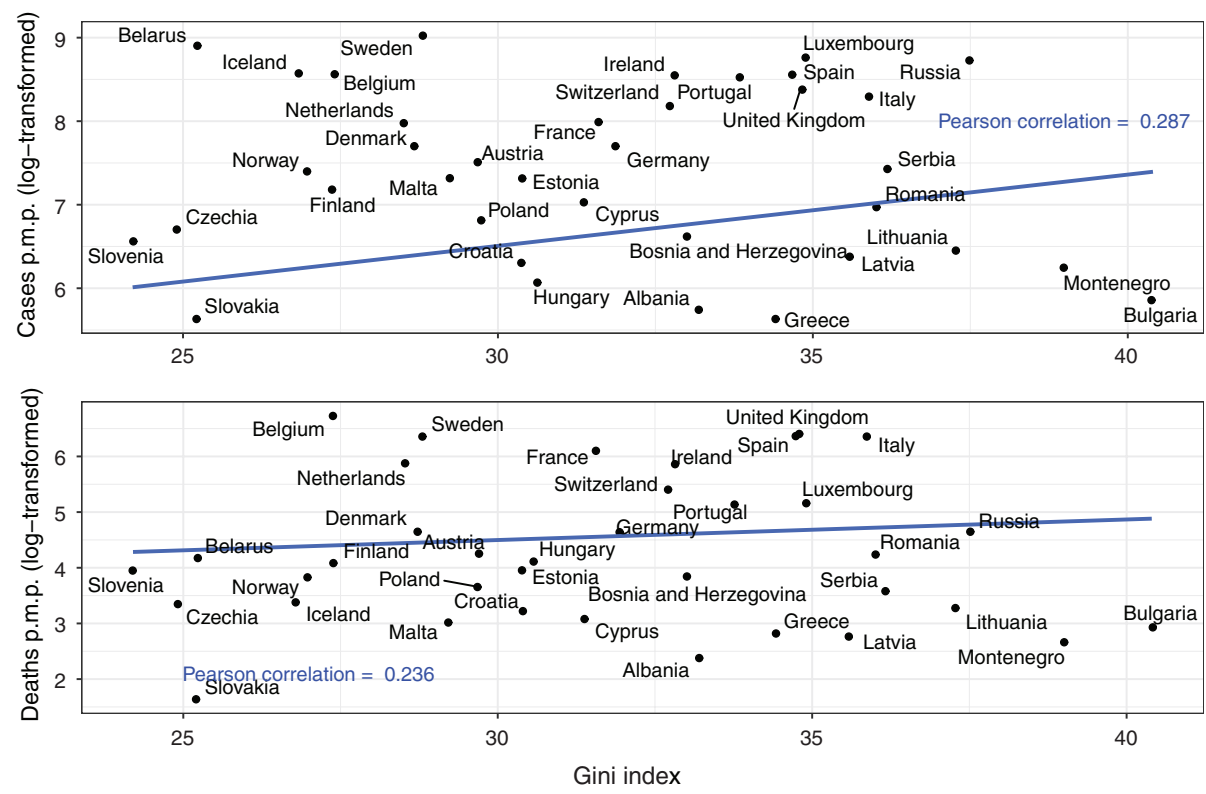

The lower panel of Figure 4 shows a positive correlation between the Gini index and the number of deaths, although it was weaker than the correlation found for infections. The Pearson's correlation estimation was $0.236(95 \% \mathrm{CI}=0.02-0.43)$. The per capita risk of death increased by $1.01(95 \% \mathrm{CI}=0.93-1.10$, se $=0.043)$ for every unit of increase in the Gini index (see column [3] of Table 2). In this case, the per capita risk increased to 1.05 after the controls were included (see column [4] of Table 2), but the confidence interval still included one $(95 \% \mathrm{CI}=0.97-1.14$, se $=0.042$ ).

The results for the other covariates are presented in columns [2] and [4] of Table 2. A higher share of the population with at least upper secondary school was connected to lower per capita risk. Our results indicate that the share of better educated people was associated with a reduction in the risk of infection of 0.99 (95\% CI $=0.97-$ 0.99 , se $=0.008)$, and with a reduction in the risk of death of $0.98(95 \% \mathrm{CI}=0.96$ 0.99 , se $=0.011$ ). Consistent with increased exposure to risk, the per capita risk of infection increased by $1.04(95 \% \mathrm{CI}=1.01-1.09$, se $=0.027)$ with the proportion of industrial workers. However, the evidence does not necessarily suggest that the proportion of industrial workers was related to the risk of death.

The more people who travelled, whether internationally or domestically, the faster the virus spread. Our results show that the risk of infection was 1.15 (95\% CI = 1.01-1.34, se $=0.070$ ) higher in countries where more flights departed. Similarly, 
Table 2:

Per capita risk of the number of infections and deaths during the first wave of COVID-19. Quasi-Poisson regressions including log of population as an offset. Standard errors are in parentheses, and $95 \%$ confidence intervals are in brackets

\begin{tabular}{|c|c|c|c|c|}
\hline \multirow[b]{2}{*}{ Variable } & \multicolumn{2}{|c|}{ Cases } & \multicolumn{2}{|c|}{ Deaths } \\
\hline & [1] & [2] & [3] & [4] \\
\hline Gini & $\begin{array}{c}1.08[1.03-1.14] \\
(0.028)\end{array}$ & $\begin{array}{c}1.04[0.98-1.09] \\
(0.027)\end{array}$ & $\begin{array}{c}1.01[0.93-1.10] \\
(0.043)\end{array}$ & $\begin{array}{c}1.05[0.97-1.14] \\
(0.042)\end{array}$ \\
\hline Education & & $\begin{array}{c}0.99[0.97-0.99] \\
(0.008)\end{array}$ & & $\begin{array}{c}0.98[0.96-0.99] \\
(0.011)\end{array}$ \\
\hline Workers & & $\begin{array}{c}1.04 \text { [1.01-1.09] } \\
(0.027)\end{array}$ & & $\begin{array}{c}1.00[0.93-1.08] \\
(0.038)\end{array}$ \\
\hline $65+$ & & $\begin{array}{c}0.83[0.77-0.90] \\
(0.038)\end{array}$ & & $\begin{array}{c}1.07[1.01-1.13] \\
(0.049)\end{array}$ \\
\hline Urbanization & & $\begin{array}{c}1.03[1.01-1.06] \\
(0.013)\end{array}$ & & $\begin{array}{c}1.05[1.02-1.09] \\
(0.017)\end{array}$ \\
\hline Flights & & $\begin{array}{c}1.15[1.01-1.34] \\
(0.070)\end{array}$ & & $\begin{array}{c}1.30[1.02-1.79] \\
(0.144)\end{array}$ \\
\hline Physicians & & $\begin{array}{c}1.32[1.06-1.64] \\
(0.112)\end{array}$ & & $\begin{array}{c}0.57[0.39-0.79] \\
(0.179)\end{array}$ \\
\hline Beds & & $\begin{array}{c}0.99[0.98-1.00] \\
(0.005)\end{array}$ & & $\begin{array}{c}0.99[0.98-0.99] \\
(0.006)\end{array}$ \\
\hline Lockdown & & $\begin{array}{c}1.01[1.00-1.01] \\
(0.004)\end{array}$ & & $\begin{array}{c}1.00[0.97-1.02] \\
(0.011)\end{array}$ \\
\hline Right party & & $\begin{array}{c}0.74[0.50-1.09] \\
(0.201)\end{array}$ & & $\begin{array}{c}0.65[0.34-1.18] \\
(0.312)\end{array}$ \\
\hline \multicolumn{5}{|c|}{ Goodness of fit } \\
\hline Deviance & $704,869.71$ & $195,864.68$ & $147,246.63$ & $20,676.46$ \\
\hline Dispersion & $20,177.68$ & $7,048.83$ & $4,126.82$ & 851.25 \\
\hline Chi sq. & $706,218.67$ & $183,269.47$ & $14,4438.64$ & $22,132.6$ \\
\hline
\end{tabular}

the decision to impose restrictions on movement helped to slow the spread of the virus. According to our estimates, each additional day that a government delayed taking measures to restrict movement, such as lockdowns, increased the risk of infection by $1.01(95 \% \mathrm{CI}=1.00-1.01$, se $=0.004)$. On the other hand, having a right-wing or centre-right government was associated with a lower risk of infection, at $0.74(95 \% \mathrm{CI}=0.50-1.09$, se $=0.201)$, and of death, at $0.65(95 \% \mathrm{CI}=0.50$ 1.09 , se $=0.312$ ). 
Per capita risk increased with urbanization. As in the case of infections, a higher share of the population living in urban areas was associated with the virus spreading more rapidly. In our sample, the risk increased by 1.03 (95\% CI $=1.01-1.06$, se $=$ $0.013)$ for each additional percentage point of urbanization. The higher risk of death $(1.05,95 \% \mathrm{CI}=1.02-1.09$, se $=0.017)$ may be explained by the saturation that existed in hospitals during the peak of the pandemic. The countries where a higher proportion of the population was aged 65 and older had a lower risk of infection, at $0.83(95 \% \mathrm{CI}=0.77-0.90, \mathrm{se}=0.038)$, but a higher risk of death, at $1.07(95 \%$ $\mathrm{CI}=1.01-1.13$, se $=0.049$ ). These findings show the two faces of this pandemic: i.e., most of those infected with COVID-19 were under age 50, while mortality was concentrated among the elderly.

The COVID-19 pandemic has tested the capacities of countries' health care systems, and has revealed weaknesses in many of them. Increasing one hospital bed per 10,000 inhabitants slightly decreased the risk of death from COVID-19 by $0.99(95 \% \mathrm{CI}=0.98-0.99$, $\mathrm{se}=0.006)$. Of all of the variables included in our analysis, we found that the highest per capita risk was associated with the number of doctors. Increasing one physician per thousand population decreased the risk of death by $0.57(95 \% \mathrm{CI}=0.39-0.79$, se $=0.179)$. However, the presence of more physicians was associated with a higher risk of infections, at 1.32 (95\% $\mathrm{CI}=1.06-1.64$, se $=0.112$ ). One possible explanation for this result is that the presence of more physicians increased the likelihood of detecting infections, either because there was a greater capacity to test for COVID-19 when tests were carried out in physician practices, or because there was an increase in the number of doctor visits by symptomatic individuals who were subsequently referred to testing.

\section{Discussion}

Evidence from past pandemics has shown that the rates of infection and mortality tend to be higher in the most vulnerable socioeconomic status groups, especially in countries with higher levels of social inequality (Bengtsson et al., 2018; Grantz et al., 2016; Mamelund, 2006; Murray et al., 2006; Sydenstricker, 1931). Moreover, evidence from recent country case studies has suggested that this pattern has persisted during the COVID-19 pandemic. Our cross-country study focused on the question of whether varying levels of income inequality were associated with differences in the numbers of infections and deaths across European countries during the first wave of the pandemic.

Unlike other studies that analysed the effects of COVID-19 during its first stage, we did not use an ad-hoc analysis period. Instead, we developed a method to determine the duration of the first wave of the pandemic. To do this, we started our analysis period on the day on which the first case was reported, and ended it on the last day for which we could update the data (January 2021). Thus, our potential study period covered one year. Then, by smoothing the daily cases and fitting the 
smoothed trend, we determined the duration of the first wave for each country. To the best of our knowledge, this is the first study that has used this approach to homogenize the comparisons between countries.

After analysing the bivariate relationships, we found a moderate positive association between income inequality, as measured by the Gini index, and the numbers of infections and deaths during the first wave of COVID-19. To some extent, the Gini index captured the presence of groups living under vulnerable conditions within a given population. Previous evidence indicates that deprived groups tend to have worse health outcomes (Bor et al., 2017; Santerre and Neun, 2012). The positive relationship we found in the bivariate models suggests that the pandemic had a disproportionate impact on disadvantaged populations.

Based on our results, we draw several conclusions. First, unlike other known pandemics, the COVID-19 pandemic triggered a simultaneous global response aimed at stopping the spread of the virus. Thus, governments around the world imposed restrictions on movement and closed borders. In Europe, the pandemicrelated lockdowns lasted approximately three months, and began an average of 20 days after the first case was reported. It appears that these measures protected countries with the highest levels of social vulnerability from the effects of the pandemic during the first wave. Indeed, there is evidence that the infection and death rates were higher during the second and third waves (Our World in Data, 2020), when the mobility restrictions were milder. We will analyse these differences in further research.

Second, methods for collecting the number of deaths varied from one country to another, which has led to underreporting in some cases (Harries, 2020; Hirsch and Martuscelli, 2020). In other words, the observed number of deaths varied across countries depending on the (unobserved) reporting policy, which may have led to biases. We intend to test our hypothesis using excess mortality as the dependent variable once data for all European countries (and for less developed countries) become available. Similarly, the number of infections may have been affected by differences in testing policies between countries. Testing levels were lower during the first wave than they were during subsequent waves.

Third, one of the characteristics of this pandemic has been the rapid speed of the spread of the virus across populations. Although the proportion of people infected with COVID-19 during the first wave who became severely and critically ill can be considered low, given the large numbers of people who were infected, this relatively small proportion resulted in high absolute numbers of critically ill people, which, in turn, placed great pressure on health care systems. In general, European countries have public and universal health care systems, which may reduce the effects of social inequity. However, our results show that even in Europe, there were differences between countries in the risk of death associated with more doctors and greater hospital capacity during the first pandemic wave. A potential explanation for this finding is that more unequal societies devote fewer resources to redistributive policies, such as health care (Mello, 2006). 
Fourth, during the first pandemic wave, not everyone had the option to stay home and telework. Essential workers continued to commute to their workplaces, and were more exposed to the virus than white-collar workers (Adams et al., 2020; Ahmed et al., 2020; Lekfuangfu et al., 2020; Sá, 2020). In turn, the work activities of these individuals increased the risk of infection for their cohabitants (Aparicio and Grossbard, 2020). Our estimates show a clear relationship between infections and the proportion of the population working in essential activities. Given that most of these workers had lower incomes, our results show another dimension of the link between income inequality and the pandemic.

In summary, we found a moderate positive association between income inequality and the numbers of COVID-19 infections and deaths in our models without controls. However, after the controls were included, the statistical significance of this association disappeared. Thus, the link between socioeconomic inequalities and infectious diseases was no longer obvious once the correlations among multiple covariates were accounted for (Brown and Ravallion, 2020). Our results are consistent with previous evidence showing that the effects of socioeconomic inequalities on health outcomes tend to be smaller in countries that already had relatively low levels of social and economic inequality prior to the onset of the pandemic (Rice, 2005; Summers et al., 2014). In further research, we intend to explore this association at the subnational level (e.g., NUTS II level), or at the individual level.

Turning to the policy implications of our findings, we recommend that governments constantly prioritize the protection of vulnerable groups in their contingency plans. On the other hand, further research is needed about, among other pandemicrelated topics, the effects of lockdowns. For instance, the closure of non-essential businesses across Europe has contributed to increased unemployment, poverty and inequality. Moreover, the impact on mental health of remaining isolated, of increased uncertainty, and of feeling vulnerable when social interactions are reestablished should be assessed.

\section{Acknowledgments}

The author would like to thank Ashira Menashe-Oren, Benjamin-Samuel Schlüter and Bruno Schoumaker for their comments on a previous version of this manuscript; and Damien Courtney, Alexia Fürnkranz-Prskawetz and Miguel Sánchez-Romero for providing useful feedback during the presentation of this research at the Wittgenstein Centre Conference 2020.

\section{ORCID}

David A. Sánchez-Páez [i] https://orcid.org/0000-0002-7828-8193 


\section{References}

Adams, A., Boneva, T., Golin, M., and Rauh, C. (2020). Inequality in the impact of the coronavirus shock: Evidence from real time surveys (Working paper DP14665). Centre for Economic Policy Research, London. https://cepr.org/active/publications/discussion_ papers/dp.php?dpno=14665

Ahmed, F., Ahmed, N., Pissarides, C., and Stiglitz, J. (2020). Why inequality could spread COVID- 19. The Lancet Public Health, 5(5), Article e240. https://doi.org/10.1016/S24682667(20)30085-2

Aparicio, A., and Grossbard, S. (2020). Intergenerational residence patterns and COVID19 fatalities in the EU and the US (IZA Discussion Paper 13452). Institute of Labour Economics, Bonn. https://ideas.repec.org/p/iza/izadps/dp13452.html

AQuAS. (2020). Coronavirus SARS-Cov-2 interactive map. Catalan Agency for Health Quality and Assessment, Barcelona. Retrieved 22 January 2021, from http://aquas.gencat. cat/.content/IntegradorServeis/mapa_covid/atlas.html

Arbel, Y., Fialkoff, C., Kerner, A., and Kerner, M. (2020). Do population density, socioeconomic ranking and Gini index of cities influence infection rates from coronavirus? Israel as a case study. Research Square. https://doi.org/10.21203/rs.3.rs-40387/v1

Bengtsson, T., Dribe, M., and Eriksson, B. (2018). Social class and excess mortality in Sweden during the 1918 influenza pandemic. American Journal of Epidemiology, 187(12), 2568-2576. https://doi.org/10.1093/aje/kwy151

Biggerstaff, M., Jhung, M. A., Reed, C., Garg, S., Balluz, L., Fry, A. M., and Finelli, L. (2014). Impact of medical and behavioural factors on influenza-like illness, healthcare-seeking, and antiviral treatment during the $2009 \mathrm{H} 1 \mathrm{~N} 1$ pandemic: United States, 2009-2010. Epidemiology $\mathcal{E}$ Infection, 142(1), 114-125. https://doi.org/10.1017/S0950268813000654

Bor, J., Cohen, G. H., and Galea, S. (2017). Population health in an era of rising income inequality: USA, 1980-2015. The Lancet, 389(10077), 1475-1490. https://doi.org/10. 1016/S0140-6736(17)30571-8

Brown, C. S., and Ravallion, M. (2020). Inequality and the coronavirus: Socioeconomic covariates of behavioral responses and viral outcomes across US counties (NBER Working Paper No. 27549). National Bureau of Economic Research, Cambridge. https://doi.org/10.3386/w27549

Buchanan, L., Patel, J. K., Rosenthal, B. M., and Singhvi, A. (2020). A month of coronavirus in New York City: See the hardest-hit areas. The New York Times, 1 April 2020. https: //www.nytimes.com/interactive/2020/04/01/nyregion/nyc-coronavirus-cases-map.html

Charu, V., Chowell, G., Palacio Mejia, L. S., Echevarría-Zuno, S., Borja-Aburto, V. H., Simonsen, L., Miller, M. A., and Viboud, C. (2011). Mortality burden of the H1N1 pandemic in Mexico: A comparison of deaths and years of life lost to seasonal influenza. Clinical Infectious Diseases, 53(10), 985-993. https://doi.org/10.1093/cid/cir644

Chen, J. T., and Krieger, N. (2020). Revealing the unequal burden of COVID-19 by income, race/ethnicity, and household crowding: US county versus ZIP code analyses. Journal of Public Health Management and Practice, 27(1), S43-S56. https://doi.org/10.1097/PHH. 0000000000001263

CIDOB. (2021). Cuáles son los gobiernos europeos: Partidos, coaliciones, primeros ministros. Barcelona Centre for International Affairs, Barcelona. Retrieved 25 May 2021, 
from https://www.cidob.org/en/biografias_lideres_politicos_only_in_spanish/organismos/ union_europea/cuales_son_los_gobiernos_europeos_partidos_coaliciones_primeros_ ministros

Crighton, E. J., Elliot, S. J., Moineddin, R., Kanaroglou, P., and Upshur, R. (2007). A spatial analysis of the determinants of pneumonia and influenza hospitalizations in Ontario (19922001). Social Science $\mathcal{E}$ Medicine, 64(8), 1636-1650. https://doi.org/10.1016/j.socscimed. 2006.12.001

Cristini, A., and Trivin, P. (2020). Close encounters on the verge of a pandemic: The role of social contacts on the spread and mortality of COVID-19 (MPRA Paper No. 103075). Munich University, Munich. https://mpra.ub.uni-muenchen.de/id/eprint/103075

Demenech, L. M., Carvalho Dumith, S. de Centena Duarte Vieira, M. E., and Neiva-Silva, L. (2020). Income inequality and risk of infectionand death by COVID-19 in Brazil. Revista Brasileira de Epidemiologia, 23, Article E200095. https://doi.org/10.1590/1980549720200095

Dunford, D., Dale, B., Stylianou, N., Lowther, E., Ahmed, M., and de la Torre, I. (2020). Coronavirus: The world in lockdown in maps and charts. BBC News, 7 April 2020. https://www.bbc.com/news/world-52103747

Elgar, F. J., Stefaniak, A., and Wohl, M. J. A. (2020). The trouble with trust: Time-series analysis of social capital, income inequality, and COVID-19 deaths in 84 countries. Social Science $\mathcal{E}$ Medicine, 263, Article 113365. https://doi.org/10.1016/j.socscimed. 2020.113365

Esteve, A., Permanyer, I., Boertien, D., and Vaupel, J. W. (2020). National age and coresidence patterns shape COVID-19 vulnerability. Proceedings of the National Academy of Sciences of the United States of America, 117(28), 16118-16120. https://doi.org/10. 1073/pnas.2008764117

Gardner, W., States, D., and Bagley, N. (2020). The coronavirus and the risks to the elderly in long- term care. Journal of Aging $\mathcal{E}$ Social Policy, 32(4-5), 310-315. https://doi.org/10. 1080/08959420.2020.1750543

Grantz, K. H., Rane, M. S., Salje, H., Glass, G. E., Schachterle, S. E., and Cummings, D. A. T. (2016). Disparities in influenza mortality and transmission related to sociodemographic factors within Chicago in the pandemic of 1918. Proceedings of the National Academy of Sciences of the United States of America, 113(48), 13839-13844. https://doi.org/10.1073/ pnas. 1612838113

Harries, D. (2020). How do different countries calculate their COVID-19 death rates? CGTN, 18 April 2020. https://newseu.cgtn.com/news/2020-04-18/How-do-different-countriescalculate-their-COVID-19-death-rates--PM3ur6PEtO/index.html

Hirsch, C., and Martuscelli, C. (2020). The challenge of counting COVID-19 deaths. POLITICO, 30 April 2020. https://www.politico.eu/article/coronavirus-the-challenge-ofcounting-covid-19-deaths/

Hopkins Tanne, J., Hayasaki, E., Zastrow, M., Pulla, P., Smith, P., and Garcia Rada, A. (2020). Covid-19: How doctors and healthcare systems are tackling coronavirus worldwide. $B M J$, 368: Article m1090. https://doi.org/10.1136/bmj.m1090

International Labour Organization (ILO). (2020). ILOSTAT database. Retrieved 25 January 2021, from https://ilostat.ilo.org/data/ 
Jijiie, A.-S., Alonso-García, J., and Arnold, S. (2019). Mortality by socio-economic class and its impact on retirement schemes: How to render the systems fairer? (Working Paper 2019/6). ARC Centre of Excellence in Population Ageing Research, Australia. https://cepar.edu.au/sites/default/files/Working\%20Paper\%202019-6.pdf

Jung, J., Manley, J., and Shrestha, V. (2020). Coronavirus infections and deaths by poverty status: Time trends and patterns. Covid Economics, 1(31), 1-58.

Kashnitsky, I., and Aburto, J. M. (2020). COVID-19 in unequally ageing European regions. World Development, 136(2020), 105170-105172 https://doi.org/10.1016/j.worlddev.2020. 105170

Kawachi, I., and Kennedy, B. P. (1999). Income inequality and health: Pathways and mechanisms. Health Services Research, 34(1), 215-227. https://europepmc.org/article/ med/10199670

Krisberg, K. (2016). Income inequality: When wealth determines health: Earnings influential as lifelong social determinant of health. The Nation's Health, 46(8), 1-17. https://www. thenationshealth.org/content/46/8/1.1

Lekfuangfu, W. N., Piyapromdee, S., Porapakkarm, P., and Wasi, N. (2020). On COVID-19: New implications of job task requirements and spouse's occupational sorting. Covid Economics, 1(12), 87-103.

Lowcock, E. C., Rosella, L. C., Foisy, J., McGeer, A., and Crowcroft, N. (2012). The social determinants of health and pandemic H1N1 2009 influenza severity. American Journal of Public Health, 102(8): 51-58. https://doi.org/10.2105/AJPH.2012.300814

Lynch, J. W., Kaplan, G. A., Pamuk, E. R., Cohen, R. D., Heck, K. E., Balfour, J. L., and Yen, I. H. (1998). Income inequality and mortality in Metropolitan areas of the United States. American Journal of Public Health, 88(7), 1074-1080. https://doi.org/10.2105/ ajph.88.7.1074

Lynch, J. W., Smith, G. D., Kaplan, G. A., and House, J. S. (2000). Income inequality and mortality: Importance to health of individual income, psychosocial environment, or material conditions. BMJ, 320, 1200-1204. https://doi.org/10.1136/bmj.320.7243.1200

Mamelund, S. E. (2006). A socially neutral disease? Individual social class, household wealth and mortality from Spanish influenza in two socially contrasting parishes in Kristiania 1918-19. Social Science $\mathcal{E}$ Medicine, 62(4), 923-940. https://doi.org/10.1016/j.socscimed. 2005.06.051

Martines, M. R., Ferreira, R. V., Toppa, R. H., Assuncao, L., Desjardins, M. R., and Delmelle, E. M. (2021). Detecting space-time clusters of COVID-19 in Brazil: Mortality, inequality, socioeconomic vulnerability, and the relative risk of the disease in Brazilian municipalities. Journal of Geographical Systems, 23, 7-36. https://doi.org/10.1007/s10109-020-00344-0

Meara, E. R., Richards, S., and Cutler, D. M. (2008). The gap gets bigger: Changes in mortality and life expectancy, by education, 1981-2000. Health Affairs, 27(2), 350-360. https://doi.org/10.1377/hlthaff.27.2.350

de Mello, L., and Tiongson, E. R. (2006). Income inequality and redistributive Government spending. Public Finance Review, 34(3), 282-305. https://doi.org/10.1177/ 1091142105284894 
Mollalo, A., Vahedi, B., and Rivera, K. M. (2020). GIS-based spatial modeling of COVID19 incidence rate in the continental United States. Science of the Total Environment, 728(2020), Article 138884. https://doi.org/10.1016/j.scitotenv.2020.138884

Mukherji, N. (2020). The social and economic factors underlying the incidence of COVID-19 cases and deaths in US counties. MedRxiv. https://doi.org/10.1101/2020.05.04.20091041

Murray, C. J., Lopez, A. D., Chin, B., Feehan, D., and Hill, K. H. (2006). Estimation of potential global pandemic influenza mortality on the basis of vital registry data from the 1918-20 pandemic: A quantitative analysis. The Lancet, 368(9554), 2211-2218. https://doi.org/10.1016/S0140-6736(06)69895-4

Nelissen, J. H. M. (1999). Mortality differences related to socioeconomic status and the progressivity of old-age pensions and health insurance: The Netherlands. European Journal of Population, 15(1), 77-97. https://doi.org/10.1023/A:1006188911462

Nepomuceno, M. R., Acosta, E., Alburez-Gutierrez, D., Aburto, J. M., Gagnon, A., and Turra, C. M. 2020. Besides population age structure, health and other demographic factors can contribute to understanding the COVID-19 burden. Proceedings of the National Academy of Sciences of the United States of America, 117(25), 13881-13883. https: //doi.org/10.1073/pnas.2008760117

Olshansky, S. J., Antonucci, T., Berkman, L., Binstock, R. H., Boersch-Supan, A., Cacioppo, J. T., Carnes, B. A., Carstensen, L. L., Fried, L. P., Goldman, D. P., and et al. (2012). Differences in life expectancy due to race and educational differences are widening, and many may not catch up. Health Affairs, 31(8), 1803-1813. https://doi.org/10.1377/hlthaff. 2011.0746

Oronce, C. I., Scannel, C. A., Kawachi, I., and Tsugawa, Y. (2020). Association between State-level income inequality and COVID-19 cases and mortality in the USA. Journal of General Internal Medicine, 35, 2791-2793. https://doi.org/10.1007/s11606-020-05971-3

Our World in Data. (2020). Coronavirus pandemic (COVID-19). Retrieved 4 February 2021, from https://ourworldindata.org/coronavirus

Papageorge, N., Zahn, M., Belot, M., Broek-Altenburg, van den, E., Choi, S., Jamison, J., and Tripodi, E. (2020). Socio-demographic factors associated with self-protecting behavior during the Covid-19 pandemic (NBER Working Paper No. 27378). National Bureau of Economic Research, Cambridge. https://doi.org/10.3386/w27378\%20

Pickett, K. E., and Wilkinson, R. G. (2015). Income inequality and health: A causal review. Social Science $\mathcal{E}$ Medicine, 128, 316-326. https://doi.org/10.1016/j.socscimed.2014.12. 031

Pirisi, A. (2000). Low health literacy prevents equal access to care. Lancet, 356(9244), 1828. https://doi.org/10.1016/s0140-6736(05)73297-9

Rehnberg, J., Fors, S., and Fritzell, J. (2019). Divergence and convergence: How do income inequalities in mortality change over the life course? Gerontology, 65, 313-322. https://doi.org/10.1159/000494082

Rice, G. W. (2005). Black November: The 1918 influenza pandemic in New Zealand. Second edition, Canterbury University Press, Christchurch. https://www.canterbury. ac.nz/engage/cup/catalogue/books/black-november-the-1918-influenza-pandemic-innew-zealand.html 
Ruiz Estrada, M. A. (2020). Can COVID-19 shows income inequality? SSRN. https://doi. org/10.2139/ssrn.3638160

Rutter, P. D., Mytton, O. T., Mak, M., and Donaldson, L. J. (2012). Socio-economic disparities in mortality due to pandemic influenza in England. International Journal of Public Health, 57(4), 745-750. https://doi.org/10.1007/s00038-012-0337-1

Santerre, R., and Neun, S. P. (2012). Health Economics: Theory, insights, and industry studies (5th ed.). South-Western Cengage Learning, Boston.

Sá, F. (2020). Socioeconomic determinants of Covid-19 infections and mortality: Evidence from England and Wales (Working paper DP14781). Centre for Economic Policy Research, London. https://cepr.org/active/publications/discussion_papers/dp.php?dpno=14781

Shkolnikov, V. M., Scholz, R., Jdanov, D. A., Stegmann, M., and Von Gaudecker, H. M. (2007). Length of life and the pensions of five million retired German men. European Journal of Public Health, 18(3), 264-269. https://doi.org/10.1093/eurpub/ckm102

Summers, J. A., Stanley, J., Baker, M. G., and Wilson, N. (2014). Risk factors for death from pandemic influenza in 1918-1919: A case-control study. Influenza and Other Respiratory Viruses, 8(3), 329-338. https://doi.org/10.1111/irv.12228

Sydenstricker, E. (1931). The incidence of influenza among persons of different economic status during the epidemic of 1918. Public Health Reports, 46(4), 154-170. https://doi. org/10.2307/4579923

Takian, A., Kiani, M. M., and Khanjankhani, K. (2020). COVID-19 and the need to prioritize health equity and social determinants of health. International Journal of Public Health, 65(5), 521-523. https://doi.org/10.1007/s00038-020-01398-z

Tam, K., Yousey-Hindes, K., and Hadler, J. L. (2014). Influenza-related hospitalization of adults associated with low census tract socioeconomic status and female sex in New Haven County, Connecticut, 2007-2011. Influenza and Other Respiratory Viruses, 8(3), 274-281. https://doi.org/10.1111/irv.12231

UNESCO. (2020). UIS. Stat. Retrieved 02 February 2021, from http://data.uis.unesco.org/ index.aspx

United Nations. (2018). World Urbanization Prospects 2018. Retrieved 25 January 2021, from https://population.un.org/wup/

United Nations. (2020). World Population Prospects 2019. Retrieved 25 January 2021, from https://population.un.org/wpp/

Ver Hoef, J. M., and Boveng, P. L. (2007). Quasi-Poisson vs. negative binomial regression: How should we model overdispersed count data? Ecology, 88(11), 2766-2772. https://doi.org/10.1890/07-0043.1

Villegas, A. M., and Haberman, S. (2014). On the modeling and forecasting of socioeconomic mortality differentials: An application to deprivation and mortality in England. North American Actuarial Journal, 18(1), 168-193. https://doi.org/10.1080/10920277.2013. 866034

Wachtler, B., Michalski, N., Nowossadeck, E., Diercke, M., Wahrendorf, M., Santos-Hövener, C., Lampert, T., and Hoebel, J. (2020). Socioeconomic inequalities in the risk of SARSCoV-2 infection - First results from an analysis of surveillance data from Germany. Journal of Health Monitoring, 5(S7), 18-29. https://doi.org/10.25646/7057 
World Health Organization (WHO). (2020). Global Health Observatory data repository. Retrieved 25 January 2021, from https://apps.who.int/gho/data/node.home

World Bank. (2020). World Bank Open Data. Retrieved 10 July 2020, from https://data. worldbank.org/

Open Access This article is published under the terms of the Creative Commons Attribution 4.0 International License (https://creativecommons.org/licenses/by/4.0/) that allows the sharing, use and adaptation in any medium, provided that the user gives appropriate credit, provides a link to the license, and indicates if changes were made. 